\title{
Costa Andrade e o lapidar da pedra da memória: enlaces entre poesia e pintura'
}

\author{
Carmen Lucia Tindó Secco \\ (Universidade Federal do Rio de Janeiro)
}

Ao Ndunduma e ao meu pai, que não se conheceram, mas partiram, desta vida, quase juntos, em setembro de 2009.

\section{RESUMO}

Análise do livro Irritação, de Wayovoka André, um dos pseudônimos literários de Fernando Costa Andrade, poeta e pintor angolano. Irritação estabelece uma correspondência entre a arte da poesia e da pintura. Propõe um diálogo entre palavras e cores, traços e escrita, faz não somente uma reflexão acerca da guerra em Angola, mas de sua própria escrita poética e pictórica.

PALAVRAS-CHAVE: poesia, pintura, Angola, Costa Andrade

\section{ABSTRACT}

Analysis of the book Irritation, of Wayovoka André, one of the literary pseudonyms of Fernando Costa Andrade, poet and painter of Angola. Irritation establishes a correspondence between the art of the poetry and of the painting. It proposes a dialog between words and colors, drawings and writing, doing a reflection not only about the war in Angola, but of his poetic and pictorial writing.

KEYWORDS: poetry, painting, Angola, Costa Andrade 
É como singela homenagem à memória de Fernando Costa Andrade que escrevo este breve ensaio sobre Irritação, livro assinado por Wayovoka André, um de seus pseudônimos artísticos, cuja singularidade é, nessa obra, tecer um diálogo, ao mesmo tempo pleno e complementar, inteiro e inconcluso, entre poesia e pintura.

O tema da correspondência das artes já foi alvo de estudos e concepções que variaram através dos tempos e em função de diferentes pontos de vista. Na Antiguidade Clássica, por exemplo, as artes eram dicotomizadas em espaciais (a pintura, a escultura e a arquitetura) e temporais (a poesia, a música e a dança). Atualmente, essa dicotomia já foi, em grande parte, ultrapassada, e isso se deve, entre outras contribuições, às dos estudos de Lessing e de Etienne Souriau, para quem:

Nada mais evidente do que a existência de um tipo de parentesco entre as artes. Pintores, escultores, músicos, poetas são levitas do mesmo templo. (...) As artes plásticas contêm um tempo essencial, sendo as artes rítmicas tão espaciais quanto as ditas artes do tempo. (SOURIAU, 1983, p. 14)

Hoje, a maioria dos estudiosos das artes sabe que essas "nunca são apenas intra-estéticas" (GEERTZ, 1999, p. 146), na medida em que se entrelaçam não só por meio de fios visíveis presentes nas relações intersemióticas entre textos literários, composições musicais e telas pictóricas, mas também por invisíveis elos que estabelecem, entre os objetos artísticos analisados, uma interconexão semiológica, cuja interpretação faz aflorarem significados submersos, inscritos no imaginário coletivo, relativo aos contextos sociais, onde se geraram as referidas obras de arte.

Para Walter Benjamin (1984, pp.181-204), é inerente a toda obra de arte um caráter alegórico, que lhe dá condições de dizer conteúdos antagônicos reprimidos e submersos; por isso, somente a arte pode diluir os eixos passionais conflitantes na vida. Somente a forma artística pode resolver questões antitéticas e eternizá-las. Concordando com o mencionado filósofo, acrescento: somente a arte consegue conjugar memória e esquecimento, guerra e paz, lágrimas e sorrisos, cores e linguagens, repensando e reinventando inquietações humanas de diferentes ordens. 
Fernando Costa Andrade é um exemplo dessa conjugação entre as artes. Artista plástico e escritor, possui o domínio da cor e da palavra, trabalhando letras e telas em diálogos de complementaridade:

Houve um momento em que a pintura me permitia uma sensação de bem-estar muito maior do que qualquer repouso, após um tempo prolongado de exercício físico. E no entanto necessitava, sempre, de libertar mais, muito mais energias nos movimentos, nas mensagens que a expressão das cores me impunha fixar na tela, ou outro suporte disponível. Verificava, na escrita, na criação poética, e na crónica, o complemento muitas vezes imprescindível, um domínio, como que dialogado e consentido entre o objecto e o autor. É inegável que a discussão, quase traumática, atingia um ponto transgressivo, em que por vezes me sentia coagido a regressar ao poema, a meio da presença diante da tela, tempos passados de distanciamento, para riscar uma palavra, um verso, apagar um som, tentar impor a decisão minha, sobre aquela intuída, na hora da criação pictórica. Não se tratava efectivamente de um conflito entre a obra e o autor. Mas substancialmente da diferença de modos de dizer, de uma e outro.

O cerne da questão, a dilaceração e a dúvida, surge nas seguintes circunstâncias: quando, dado por concluído o verso, o poema, uma irreprimível força, envolta de ansiedades, impõe novas palavras e ou imagens, que não diz, mas fixa em cores, ou mesmo apenas numa tonalidade única, gestos que dizem o que ficou por dizer no verso. Nem sempre, mas quase sempre para complementar. Muitas vezes, tantas vezes para deixar adivinhar outra vertente de dizer, um outro modo de comunicar. (ANDRADE, inédito a ser publicado no livro Pensando África)

Poeta e pintor, jornalista e escritor, militante e político, Costa Andrade, natural do Lépi, uma localidade da província do Huambo, em Angola, nasceu no ano de 1936 e faleceu em 18 de setembro de 2009. Tanto nas vivências culturais, como nas profissionais, se caracterizou pela pluralidade de saberes e fazeres, de rostos e nomes que sempre buscaram expressar sua versátil riqueza interior e a gama variada de conhecimentos e pendores para diferentes artes. Assim, ao longo da vida pessoal, política e artística, adotou diversos pseudônimos: Angolano de Andrade, Nando Angola, Africano Paiva, Flávio Silvestre, Fernando Emilio, Ndunduma e Ndunduma wé Lépi, este último, nome de guerra usado nos anos de guerrilha, no Leste de Angola, nas décadas de 1960 e 1970. Na pintura, assinou apenas Andrade e, nas obras em que, passou a despir, em grande parte, a roupagem engajada, dominante na primeira fase de sua poesia, assumindo um lirismo mais subjetivo, amoroso e 
menos militante - entre as quais Limos de lume (1989), Memória de púrpura (1990), Irritação (1994) -, adotou o heterônimo Wayovoka André que, no último livro aqui citado, acumula a dúplice máscara de pintor e poeta.

$\mathrm{Na}$ antecena de Irritação, há uma correspondência epistolar entre Wayovoka André e o consagrado Ruy Duarte de Carvalho, cujas faces culturais, artísticas e políticas, como as de Fernando Costa Andrade, também são múltiplas: poeta, romancista, pintor, cineasta, antropólogo, ensaísta, entre outras. Esse artifício inovador de abrir o livro com as duas missivas funciona como espécie de prefácio à obra. Na primeira carta, datada de 22/08/1990, o jovem poeta Wayovoka - que declara ter vinte e sete anos - escreve ao mais velho Ruy Duarte, pedindo-lhe sincera avaliação do livro que pretende publicar pela União dos Escritores Angolanos.

Tendo em vista que, no mundo contemporâneo dos nets, missivas desse tipo, de modo geral, caem em desuso, observa-se que a estratégia epistolar, colocada como preâmbulo do livro, ganha um sentido mais subjetivo e estético, instaurando, de saída, uma franca reflexão acerca das artes e dos intercâmbios criativos entre estas. A escolha de Ruy Duarte foi bastante significativa, justificando-se por ser também ele exímio artífice de palavras e imagens. A segunda epístola prefacial, assinada por Ruy, se constitui como profundo exercício metapoético, por meio do qual é discutida a inteireza da palavra poética, antes mesmo da escrita. Ruy Duarte teoriza acerca do valor da memória e das representações plásticas; do fluir límpido da linguagem, quando esta alcança o silêncio pleno, por meio do qual a Palavra é, no momento fugaz de reencontro com sua dimensão sagrada original. Avalia a escrita do jovem Wayovoka André, apalpando-lhe a rija escritura poética, cuja concretude figurativa [sic] opera não só com palavras e silêncios, mas também, com cores e formas:

É outra, a lapidação do verbo, e a escrita então não pode ser senão a imagem só de uma palavra que a idéia, essa, afeiçoou à forma (leia-se fôrma) da memória. Dá o que dá, não sou juiz, mas sei que a palavra lapidada é uma palavra rija. Falava-lhe de forma, agora é de textura que vou tentar dizer-lhe (...) a idéia destilada até ao gota-a-gota da palavra limpa, como você faz, não apenas se concentra, para durar, na extrema economia que utiliza, ela se torna sólida, mineraliza a face e o texto soa agreste. É já cascalho. E isso, aqui lhe digo, é bom, me dá prazer sentir. E dá-me para pensar. Da compreensão é que se inventa a prova, a dura pedra, o diamante, e é no cascalho que o brilho se dá. E tudo poderia ser só pó ... (CARVALHO, In: ANDRÉ, 1994, p. 10)

A análise de Ruy Duarte de Carvalho é, desse modo, uma lição de metapoesia; porém, não só: manifesta-se, ainda, como pura 
poesia, despertando os sentidos dos leitores para uma interpretação mais aguda do livro Irritação, do jovem poeta angolano. As palavras de sua missiva, transcritas na citação anterior, fazem com que seja depreendida, de imediato, uma viva intertextualidade entre os poemas de Wayovoka André e os do poeta brasileiro João Cabral de Melo Neto, a partir da imagem da pedra que alegoriza a dureza, o rigor, a exatidão de um lirismo contundente, quase "antilírico". Tanto em Cabral, como em Wayovoka, a pedra é recorrente e, metaforicamente, plasma, de forma concreta, a agudeza da palavra poética.

A pedra é risco, dissonância, aguça a lucidez da leitura, representa a busca de significados cortantes como lâminas, ou seja, de sentidos açulados por uma geografia árida, óssea, que persegue a materialização das ideias e denuncia o emparedamento do sujeito poético, em meio aos longos anos de guerra. A pedra fere, agride, obstrui; contudo, também, atrita, rala, produz outras significâncias que possibilitam inovadoras construções.

Em Irritação, poemas e imagens se interpenetram em jogos de claro e escuro, cores e palavras. Na tela inicial, um traço vermelho como um rio de sangue corta a "noite concreta" e deixa o "poeta sombrio" (ANDRÉ, 1994, p. 15); rasga-lhe a consciência e abre sua percepção para outras sensibilidades. Torna-se, assim, risco infinito, fazendo com que, graficamente, a poesia se construa como um intrínseco diálogo com a pintura que, por sua vez, também se delineia, poeticamente, à procura de sentidos mais belos e humanos, capazes de ultrapassarem as cenas dolorosas da guerra civil em Angola, ainda nítidas na memória.

O poeta-pintor Wayovoka André opera com palavras e imagens medidas, grafadas por meio de vocação memorial. As lembranças agem como suporte do tempo e do verbo. No lugar da folha de papel, a pedra - lousa em que é esculpida e talhada a poesia. $\mathrm{O}$ apuro e esmero do verso se ampliam e se estendem à pesquisa dos traços e dos tons cromáticos, assinalando a pintura com o mesmo rigor estético com que são urdidos os poemas. O minimalismo dessa escrita poético-pictórica aprofunda veios e traços, veias e sangue, que fazem pulsar a carne das palavras, a plasticidade erótica de um colorido sensível e vital.

A primeira parte de Irritação se intitula "Voz", vocábulo escrito, sozinho, no centro de uma página em branco. A seguir, a segunda tela é um poema concreto, grafado em preto, sobre um fundo acinzentado e sombrio, entre o desenho de duas pedras: "O/ A /PERTO / D' ÁGUA/ EN T RE/ PEDRA/ FAZ/ O HOMEM/ MUDAR"(ANDRÉ, 1994, p. 19, grifo do autor). Mineraliza-se o silêncio: a voz, entre as rochas que comprimem a garganta do poeta, se apresenta como dura imagem da censura, expressando visualmente a angústia de um tempo em que os fuzis se sobrepunham ao lirismo, aos afetos da (na) poesia. 
O "aperto d'água" entre pedras trava o fluir da linguagem e da liberdade. A consciência dessa agonia leva o homem a mudar, a procurar sua autêntica voz, há tanto tempo calada. O poema se transforma em "canto irritado" (ANDRÉ, 1994, p. 21), vai ao encalço do chão sereno do outrora, entoado antes da guerra (ANDRÉ, 1994, p. 24-25), pois, no presente, o ar e o pão são exíguos, a palavra é muda. A escritura poética se mostra, desse modo, irada, o que se constitui como uma forma de resistência à destruição dos sonhos e ao proliferar do pranto e da dor em Angola: "Arderam as armas e as vidas" (ANDRÉ, 1994, p. 22).

Como relatar memórias, supor futuros, se o presente do sujeito poético é perpassado por tantas destruições e estilhaços?!

São tantas as metáforas, as redes de conceitos que esquadrinham a paz, mas, no real, o poeta esbarra, o tempo todo, com a guerra e sabe que esta é "morte das ideias" (ANDRÉ, 1994, p. 33). Não obstante, ele possui a consciência de que, para alcançar a paz, tem de dizer a guerra. A relação morte/vida se manifesta, assim, como complementaridade: "só a guerra faz as teias da paz" (ANDRÉ, 1994, p.33). Esta, para o eu-lírico, se institui como "contenção irritada do desejo" (ANDRÉ, 1994, p.30).

O sema-chave que atravessa o livro e lhe dá título é, portanto, irritação. Este vocábulo possui diversas significações dicionarizadas: impaciência, indignação, exasperação, excitação, incitação, desejo. Remete, por conseguinte, para duas semânticas diferentes: a da repulsa, marcada pela impaciência, indignação, raiva, e a da atração, que veicula os significados de excitação, incitação, desejo. No livro de Wayovoka André, estão presentes esses dois campos semânticos, pois há, de um lado, a indignação com a inexistência da paz e, de outro, a excitação pela lapidação constante do verbo poético.

O sujeito lírico de Irritação procede a um desbastamento da memória e da linguagem, até encontrar desta a ossatura, limpa de qualquer gordura ou excesso. Como alerta Ruy Duarte em sua carta-prefácio, a face mineralizada dos vocábulos faz a textura poética soar agreste, como cascalho, dura pedra, diamante. Estes minerais, destarte, se convertem nos materiais dessa escrita poética que persegue, sempre e desassossegadamente, o brilho das palavras.

Irritação é um canto-desabafo, um canto-indignação com "o futuro/ no chão/ entulho/ exangue/ da guerra" (ANDRÉ, 1994, p. 27). O sujeito lírico quer a paz; deseja a harmonia cósmica que pulsa, latente, como "a força da água indômita que nem comporta retém" (ANDRÉ, 1994, p. 27). Tal vigor é semelhante ao do caudal da linguagem que corre, impetuosa, para desaguar nas profundezas do poema. Entre pedras, água, palavras e sangue, lateja, no âmago do eu-poético, uma forte excitação para "viver a vida" (ANDRÉ, 1994, p. 30), "acabar a guerra" (ANDRÉ, 1994, p. 31), "escrever o poema" (ANDRÉ, 1994, p. 31-32). 
Na parte denominada "VOZ", o eu-lírico se irrita, diante de inúmeras repetições de vocábulos que perderam o viço, a credibilidade, e indaga: "Como falar de paz e ter de matar?" (ANDRÉ, 1994, p. 34) Ele quer recuperar a voz silenciada, e clama pela "ROSA/ABS/ TRACTA" (ANDRÉ, 1994, p. 37). Que rosa é esta sobre fundo cor-de-rosa? A de Hiroxima, "bomba-pomba da paz"?! Ou a de Drummond, a crítica e questionadora "rosa do povo"?! Ou, ainda, a flor do afeto, que incita o coração dos poetas?!

Sintomaticamente, é essa rosa abstrata que, funcionando como um poema pictórico ou uma pictografia lírica, abre a segunda parte do livro de Wayovoka André, intitulada "BEIJO" (ANDRÉ, 1994, p. 39). Enquanto, no primeiro bloco da obra, a voz se encontra apertada na garganta, entre as duas pedras da angústia, aqui, o amor se expressa em "beijo raivoso", "voz gritada" (ANDRÉ, 1994, p. 43). Raiva e ternura exprimem os sentimentos ainda contraditórios do sujeito lírico; afinal, estes costumam ser, em geral, tributários dos contextos sociais e culturais em que surgem. Em razão de tantos anos de guerra em Angola, não poderia ser diferente.

Nesta segunda parte do livro, amor e beijo instigam desejos adormecidos no poeta; a pele do poema se eriça, irritada - adjetivação esta que passa, agora, a ter o sentido de "incitada", "excitada". O erotismo, desse modo, se revela intenso, verticalmente, penetrando a estrutura poemática que, como uma linha em pé, adentra o cerne do ser e da linguagem.

Mel, mar, gota, vida (ANDRÉ, 1994, p. 44) são semas de doçura que se colocam em posição contrária à angústia inicial, presente no livro. Terra, água, ar, elementos da natureza e da vida percorrem o fio dos poemas como pão e labor dessa construção, simultaneamente, literária e pictórica. Um alfabeto de sensações e sentimentos amenos é cantado e decantado por cada letra que encabeça os poemas: "a" do "amor", "b" do beijo", "c" de "calma", e assim por diante. Há um novo soletrar de emoções, doces como a paz sonhada e desejada. Há uma procura de liberdade criadora, metaforizada pelo "sentido ardente do horizonte" (ANDRÉ, 1994, p. 46) e pela pintura abstrata que rompe com os contornos realistas da arte.

Entre conceitos e contenções, a poesia se afunila, numa procura órfica de significâncias poéticas inovadoras e abissais. Embora os poemas, por vezes, expressem medos, guerras, dores, os desenhos e as pinturas em tons róseos e azuis, mesmo em meio à penumbra, abrem espaço para o amor e a esperança. Os opostos, então, nitidamente, se complementam, assim como acontece com a voz e o beijo, com a "rosa/flor abstrata" e a "sombra/concreta/ feliz", com as "figuras/ações" e palavras/fonemas sobre páginas em branco, tingidas de cores e novas sensibilidades. 
Após a descoberta amorosa, a noite se torna abstrata e a insônia se faz concreta, despertando, com intensidade, o dia e o amor (ANDRÉ, 1994, p. 49). As palavras se agudizam e o verbo "irrita" ultrapassa o significado de mera impaciência, ressemantizando-se e afinando-se com os sons e sentidos penetrantes do desejo, da vida e da própria poesia.

Nos poemas das páginas 56 a 61 de Irritação, volta uma exasperação com a perda de tempo provocada pela guerra, mas o beijo doce ameniza esse agastamento e se transforma em aroma volátil. Em meio às metáforas da água, luz, movimento, mar, garça, gaivota, sonho e espuma, a pedra se liquidifica e se volatiza, confundindo-se com o voo da poesia.

"ALITERAÇÃO" (ANDRÉ, 1994, p. 65) é a parte do livro mais intensamente permeada por reflexões metapoéticas acerca de sons, cores, palavras que compõem os poemas. O rosa do fundo da tela dialoga com o da linguagem poemática, metaforizando a mesclagem do vermelho da guerra com o branco da paz almejada. O eu-lírico anda por entre clarões e estrondos de bombas (ANDRÉ, 1994, p. 69). O frio do medo alitera sua espinha dorsal e a do poema. Da página 69 à 73, há versos e estrofes em umbundo, com a tradução, ao lado, em língua portuguesa. Ao sentir a morte tão próxima suponho -, esse sujeito lírico traz, para alguns de seus poemas, a afetividade própria da língua de origem, a que melhor traduz seus sentimentos, e a memória de lendas das tradições locais. Ele tem o corpo na guerra; mas o coração com a amada, Lahundi (ANDRÉ, 1994, p. 72 e p. 73). Esta morre, quando vai à fonte; o balaço que a atinge é, plasticamente, representado pela tela da página 75 , onde o "choque", o baque do corpo afundando, após o tiro, é expresso pelo círculo desenhado na água. É tiro, é morte, é o fim do caminho. Dor de amor que, paradoxalmente, leva a outras gestações lírico-existenciais, a inovadores enlaces entre pintura e poesia. Água na pedra, gestação (André, 1994, p.79): "eco de luz que conduz ao humano" (ANDRÉ, 1994, p. 75). Construção do poema: água da palavra, força do poético.

Irritação se encerra com uma explosão: bombas e mortes estilhaçam vidas e sílabas, palavras e fonemas, evidenciando o dilaceramento do sujeito lírico. É evidente, aqui, o diálogo com a Poesia Concreta, dos irmãos Campos, com o Poema Processo, de Décio Pignatari, referências incontornáveis do movimento da Poesia Experimental no Brasil dos anos 1960-70.

Uma das belas inovações de Irritação é o intertexto - um pictograma poético - que entremeia as partes do livro, dialogando, horizontalmente, com os poemas impressos nas folhas brancas. Esse intertexto gráfico é constituído por dez telas coloridas, nas quais são escritos versos e estrofes, que, lidos na vertical, apresentam encadeamento, formando um grande e único poema pictural: 


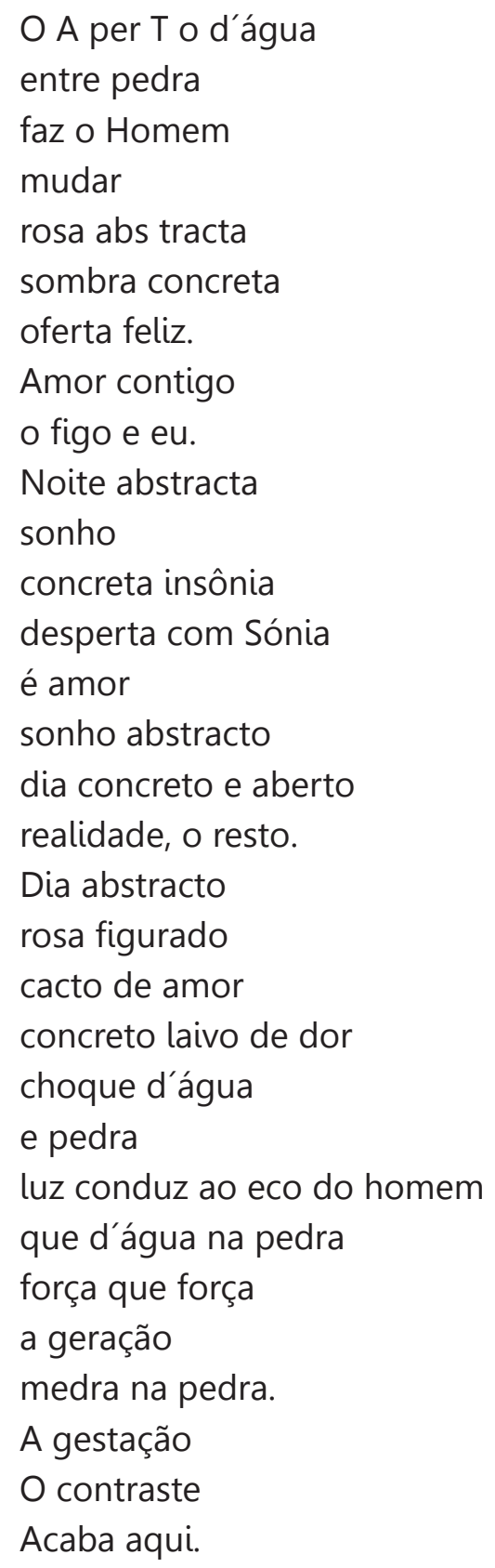

A leitura do intertexto deixa entrever tênue esperança gestando uma geração, que, em meio a tiros, pedras e perdas, a bombas, medos e paradoxos, ainda assim, tenciona reencontrar "o amor, o mel, o azul" (ANDRÉ, p. 53), "a lenda do sonho, a espuma, a gaivota" (ANDRÉ p. 61), "a alegria que iguala os homens" (ANDRÉ, p. 71).

Irritação, desse modo, faz da irritação não só indignação, mas também desejo de paz, funcionando como espécie de libelo contra a guerra e a destruição em Angola. Ao mesmo tempo que realiza a crítica de uma época, abre asas ao sonho, efetuando uma correspondência plena entre letras e telas. Torna-se, por conseguinte, clara a metáfora da pena e do pincel - que cruza toda esta obra do heterônimo Wayovoka André - e que, de certa forma, também se encontra sugerida pela tela de Henrique Abranches, inserida na capa do livro. 
Lembrando as palavras de Paula Tavares citadas na epígrafe deste ensaio, observa-se, ao fim e ao cabo, que "a linguagem da cor completa o círculo", deixando, não obstante, abertas e pulsantes, as "veias tensas" de um lirismo intersemiótico, que, profundamente, entrelaça literatura e artes plásticas.

\section{REFERÊNCIAS BIBLIOGRÁFICAS}

ANDRADE, Fernando Costa. (Ndunduma). Um rio cheio de sede. Catálogo de exposição de pintura. Luanda: Instituto Camões e Centro Cultural Português, s.d.

Ascendências (crestomacia pessoal evocativa). Reverência aos 30 anos da Independência nacional. Prefácio de Tânia Macedo. Luanda: Kilombelombe, 2005.

"A Cor da Palavra ou a Palavra das Cores" (inédito, 2008). In: SECCO, Carmen Tindó; SALGADO, Maria Teresa; JORGE, Sílvio Renato. Pensando África. Alguns textos do III Encontro de Professores de Literaturas Africanas, UFRJ, BN e UFF (2007). Rio de Janeiro: Biblioteca Nacional (no prelo, previsão para fim de 2010).

ANDRÉ, Wayovoka (Fernando Costa Andrade). Irritação. Poesia agora. Lisboa; Luanda: Reproscan; Sonangol e Lito-Tipo, 1994.

BENJAMIN, Walter. Origem do drama barroco alemão. Trad. de Sérgio Paulo Rouanet. São Paulo: Editora Brasiliense, 1984.

CARVALHO, Ruy Duarte. Carta-prefácio. In: ANDRÉ, Wayovoka (Fernando Costa Andrade). Irritação. Poesia agora. Lisboa; Luanda: Reproscan; Sonangol e Lito-Tipo, 1994.

GEERTZ, Clifford. O saber local. 2.ed. Petrópolis: Ed. Vozes, 1999.

LESSING, G. E. Laocoonte, o sobre los limites de la pintura y la poesia. Trad. De Enrique Palau. Barcelona: Editorial Ibéria, 1957.

SOURIAU, Etienne. A correspondência das artes. Trad. de Maria Cecília Pinto e Maria Helena Cunha. SP: Cultrix; EDUSP, 1983.

TAVARES, Ana Paula. In: ANDRADE, Fernando Costa (Ndunduma). Um rio cheio de sede. Catálogo da exposição de pintura de Fernando Costa Andrade Ndunduma. Luanda: Instituto Camões; Centro Cultural Português, s.d., p.16.

\section{NOTAS}

1 Este ensaio é resultado de parte de minhas pesquisas acerca do diálogo intersemiótico entre poesia e pintura, que venho desenvolvendo como pesquisadora 1 do CNPq, desde 2000. Constitui, também, uma reflexão sobre a significação dos afetos na poesia de Angola, tema de meu projeto de Pós-Doutorado, cujo estágio foi realizado na Universidade Federal Fluminense, sob a supervisão da Dra. Laura Padilha, e, em Moçambique, tendo a interlocução do Dr. Lourenço do Rosário. 


\section{ANEXOS}

WAYOVOKA ANDRE

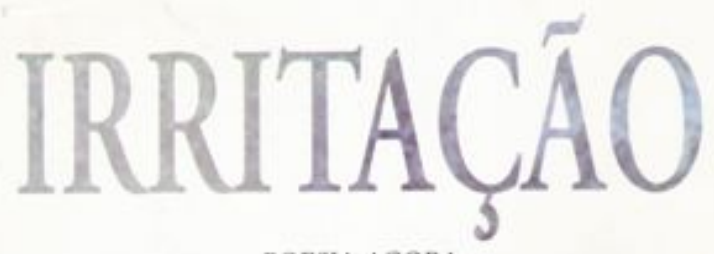

POESIA AGORA



sombra

abstracta

noite

concreta

poeta

sombrio 

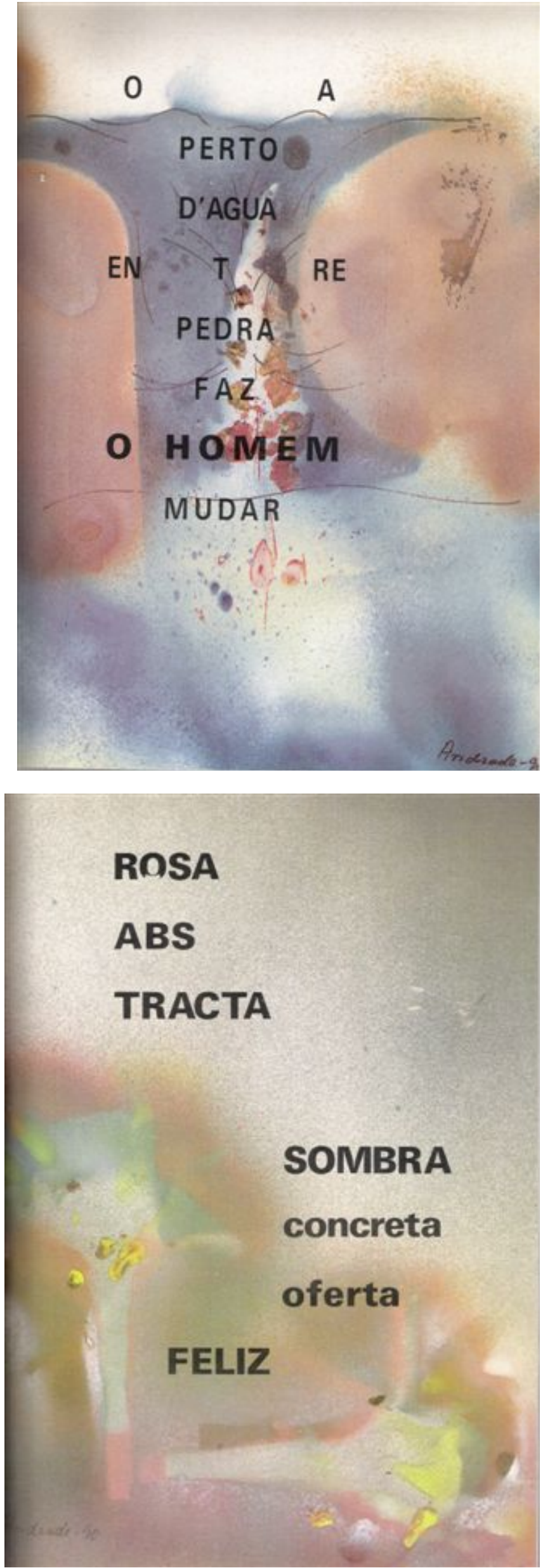


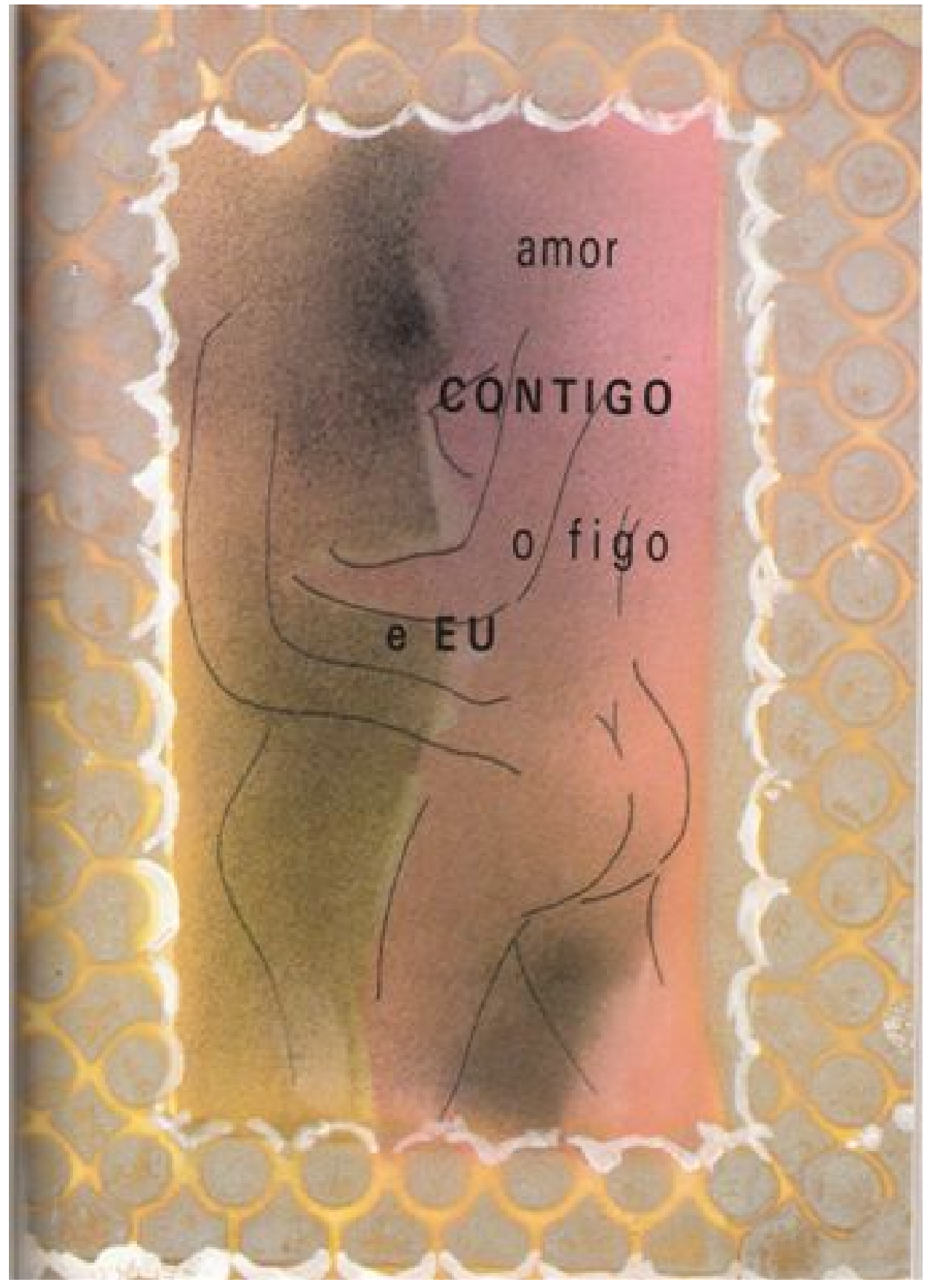

22 GBPYL-Revista do Núcleo de Estudos de Literatura Portuguesa e Africana da UFF, Vol. 3, n 5, Novembro de 2010 


\section{NOITE}

\section{ABSTRACTA}

SONHO

\section{CONCRETA}

\section{INSÓNIA}






24 GBPYL-Revista do Núcleo de Estudos de Literatura Portuguesa e Africana da UFF, Vol. 3, n 5, Novembro de 2010 


\section{DIA}

\section{ABSTRACTO}

\section{ROSA}

\section{figu \\ rado}

cacto

de amor

con

creto

\section{laivo de DOR}




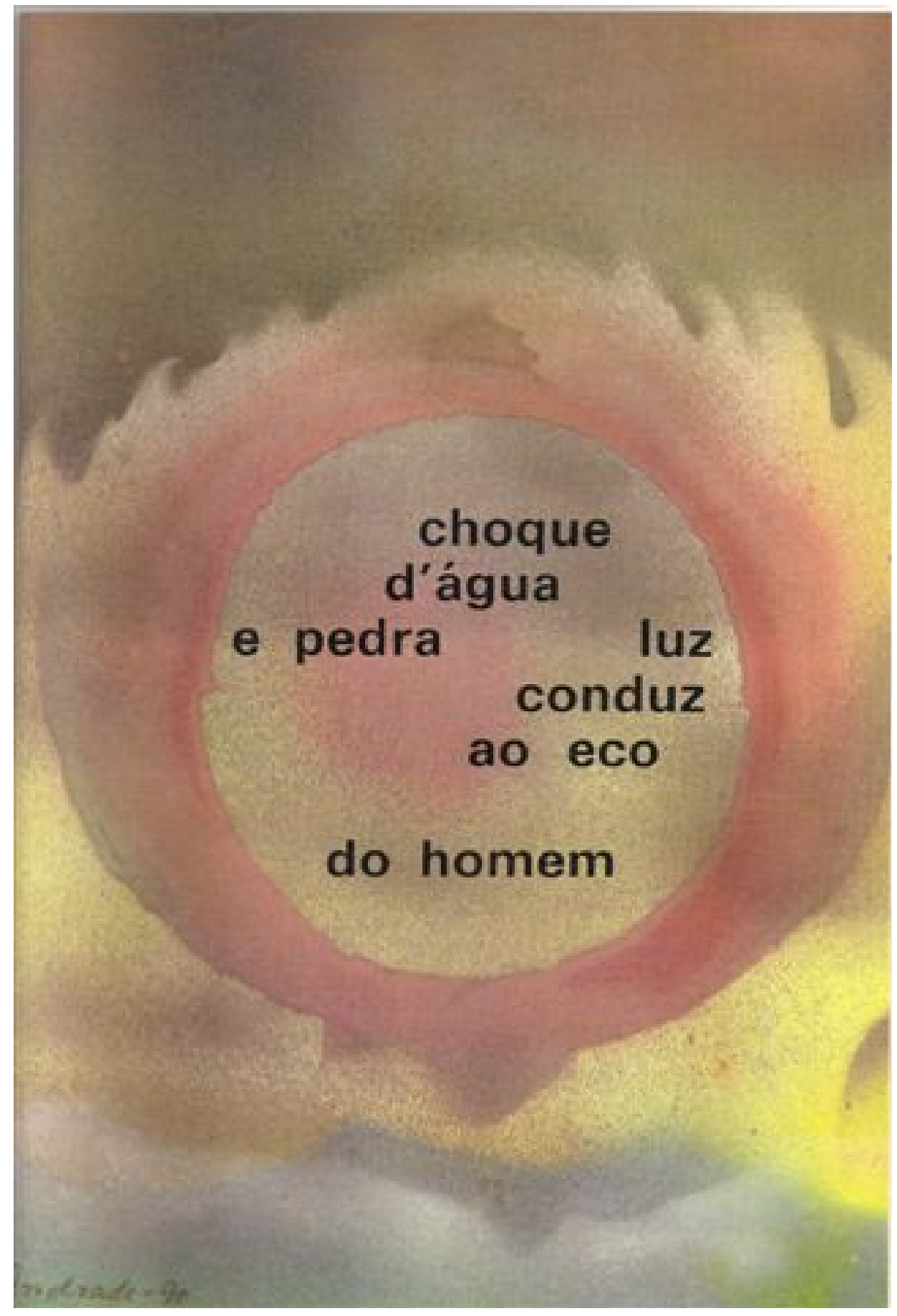




\section{que}

?água

na

\section{pedra}

17)

FORCA

que força
a geraçã
medra
na pedra

\section{A GESTAC̣Ão}




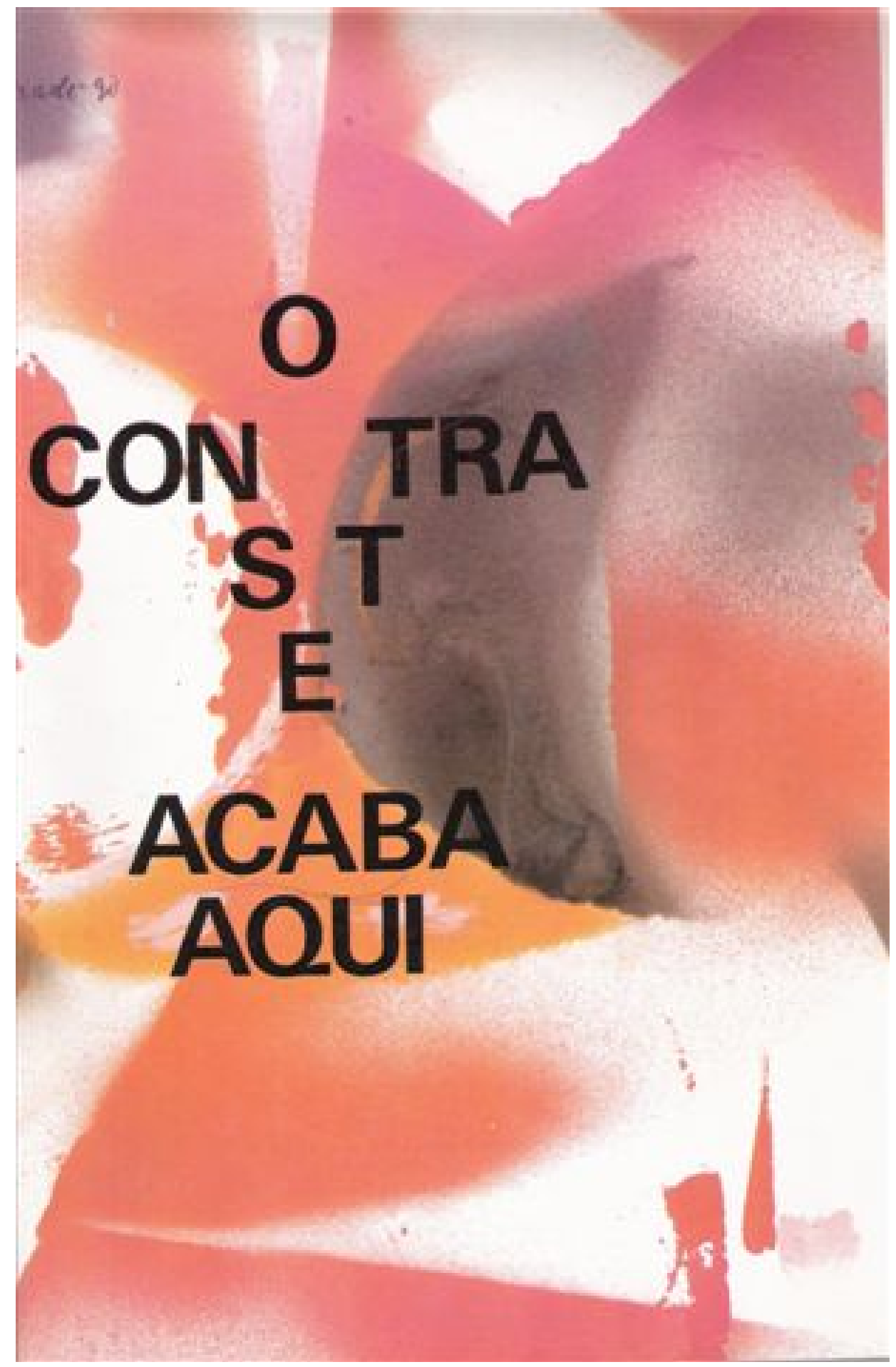

